\title{
QUANTITATIVE METHODS FOR STUDIES ON VAGINAL FLORA
}

\author{
M. Wilks, R. N. Thin* and Soad TabaqChali \\ Departments of Medical Microbiology and *Genital Medicine, St Bartholomew's \\ Hospital, West Smithfield, London EC1A $7 B E$
}

\begin{abstract}
Summary. Three recently described methods for quantitative sampling of the bacterial flora of the vagina were evaluated and none proved satisfactory. In a third of the samples, paired swabs showed large differences between the two weights of vaginal secretion collected by this method, and the recovery rate of bacteria deliberately added to test swabs was unsatisfactorily low. A calibrated loop gave a wide variation in the amount of secretion collected, due to variations in density and viscosity of the secretion. When secretion was collected with a calibrated pipette, it was often difficult to expel the collected volume from the pipette for testing. A simple weight-based method was devised in which a loop was used to collect an undefined volume of secretion for weighing in a tube of transport medium before homogenisation and quantitative bacteriological testing. Initial assessment indicates this to be a satisfactory method for quantitative studies of the vaginal bacterial flora.
\end{abstract}

\section{INTRODUCTION}

There is no generally accepted concept of normal bacterial flora of the vagina, whose complexity has become increasingly apparent since Döderlein's comprehensive report in 1892 (cited by Galask, Larsen and Ohm, 1976). Since then, most studies have been based on purely qualitative methods, often to detect only aerobic organisms; the results of these studies have been reviewed and the disparity among the findings in different reports has been discussed by Galask et al. (1976). In contrast, quantitative studies of the flora of the gastro-intestinal tract have not only established an agreed concept of normal flora but have also shown how changes in that flora relate to intestinal disorders (Tabaqchali, 1970). This advance has been made possible by the introduction of improved bacteriological techniques for the isolation of anaerobic organisms (Hungate, 1950; Holdeman, Cato and Moore, 1977) and by the development of reliable quantitative sampling techniques (Clarke, 1977). During the last few years several groups of workers (Levison et al., 1977; Onderdonk et al., 1977; Lindner, Plantema and Hoogkamp-Korstanje, 1978) have developed quantitative sampling techniques to collect a defined volume or weight of vaginal secretion, for analysis by the improved anaerobic methods. This paper reports our evaluation of these techniques and describes a method that we have subsequently devised.

\section{MATERIALS AND METHODS}

\section{Assessment of balance}

An Oertling R 20 balance was used and its accuracy was assessed by repeated estimations of a 0.02-g standard mass (Griffin and George, London) in the presence and absence of a 50-g standard mass.

\section{Anaerobic chamber}

The chamber, which has been fully described by Tabaqchali, Fiddian and Atkinson (1979),

Received 17 Jun. 1981; accepted 31 Jul. 1981.

Requests for reprints should be sent to Dr S. Tabaqchali. 
consists of a polyvinyl flexible bag attached to a metal airlock and with two sets of glove ports and rubber gloves. It contained an atmosphere of $5 \% \mathrm{CO}_{2}, 10 \% \mathrm{H}_{2}$ and $85 \% \mathrm{~N}_{2}$ and two thermostatically controlled fan heaters maintained the temperature at $35^{\circ} \mathrm{C}$. The chamber was used for the preparation of some culture media, for the handling and homogenisation of specimens and for the incubation of anaerobic cultures.

\section{Transport medium}

Commercially produced tubes (Gibco Biocult, 3 Washington Road, Paisley PA 4EP Scotland), containing $8 \mathrm{ml}$ of semisolid Cary-Blair medium in an atmosphere of oxygen-free $\mathrm{N}_{2}$, were used for some experiments. For others, a modified Cary-Blair medium without agar and with additional reducing agents was prepared; agar-free Cary-Blair medium was boiled under oxygen-free $\mathrm{CO}_{2}$ and transferred to the anaerobic chamber where cysteine $\mathrm{HCl}(0.5 \mathrm{mg} / \mathrm{ml})$ and sodium formaldehyde sulfoxolate $(0.3 \mathrm{mg} / \mathrm{ml})$ were added. The reducing agents were added after the partial reduction effected by boiling to minimise their oxidation, because oxidised reducing agent is toxic for some fastidious anaerobes (Holdeman et al., 1977). The medium was dispensed into tubes in 2-ml volumes and removed from the chamber for sterilisation by steaming for $15 \mathrm{~min}$ on 3 successive days.

\section{Methods of sampling}

Three types of sampling method were examined.

Indirect estimation of weight of secretion collected by swab was based on the method of Onderdonk et al. (1977) in which two swabs, one of them preweighed, are inserted sequentially into the posterior fornix of the vagina. One swab is then inserted into Cary-Blair transport medium for bacteriological analysis and the other reweighed to provide an estimate of weight of the sample tested. The validity of this indirect method of quantitation was tested by the use of duplicate weighed swabs, each of which was reweighed after sampling. Three types of swab were tested: Q-tips (Cheesebrough Products, Connecticut, USA), Exogen non-coated swabs and Exogen albumin-coated swabs (Exogen Ltd, Bairdmore Street, Clydebank, Strathclyde, Scotland). Correlation coefficients were calculated between the paired weights of secretion collected.

Sampling of secretion by volume. Calibrated 10- $\mu$ l loops (Nunc, Kumstrup Roskilde, Denmark), Eppendorf pipettes (Eppendorf, Hamburg, West Germany) and Finn pipettes (Jencons, Mark Road, Hemel Hempsted, Herts) were each used for collection of a defined volume of vaginal secretion, as much as possible of which was expelled into a tube of modified Cary-Blair medium.

Sampling of secretion by weight. Vaginal secretion was also collected in either Pastette "S" sterile transfer pipettes (Alpha Laboratories Ltd, 169 Oldfield Lane, Greenford, Middlesex UB6 $8 \mathrm{PW}$ ) or sterile metal loops and the sample was smeared on the sides of a weighed tube of modified Cary-Blair medium. The tube and contents were then briefly agitated on a Rotamixer (Hook and Tucker Instruments, Vulcan Way, Croydon, Surrey CR0 9UG) to disperse the secretion into the medium and reweighed to give the weight of the sample.

\section{Homogenisation of specimens}

After collection of the specimen by one of the above methods, the inoculated tube was transferred immediately into the anaerobic chamber. The contents of the tube were homogenised for up to $10 \mathrm{~min}$ in the chamber by one of the following methods. 1: vortexing alone on a Rotamixer. 2: vortexing with glass beads (diameter $1-2 \mathrm{~mm}$ or $3-5 \mathrm{~mm}$ ). 3 : transferring the tube contents to a sterile plastic bag which was treated in a Stomacher Lab-Blender 80 (Baird and Tatlock, PO Box 1, Romford, Essex RM1 1HA).

Progress of homogenisation was assessed by noting the dispersal of the cotton fibres in specimens taken with a swab (Onderdonk et al., 1977) or the disintegration of vaginal mucus and development of a uniform turbidity in specimens taken by pipette or loop. A bacteriological assessment of the effect of homogenisation was made with an overnight broth culture of 
Staphylococcus aureus (NCTC6571), whose viable count was determined from serial dilutions in saline $(0.8 \% \mathrm{w} / \mathrm{v})$, spread in $100-\mu \mathrm{l}$ volumes on blood-agar plates and incubated; $100-\mu \mathrm{l}$ portions of the culture were also either added to sterile Exogen non-albumin-coated swabs, which were then inserted into tubes of Cary-Blair transport medium or inoculated directly into such tubes. The contents of each inoculated tube were then homogenised as above and samples removed for viable counts, expressed as colony-forming units $(\mathrm{cfu}) / \mathrm{ml}$.

\section{Bacteriological examination of vaginal specimens}

Specimens for bacteriological analysis were collected with a sterile metal loop by sampling method 3. Homogenisation was performed by vortexing for 2 min with glass beads (1-2 $\mathrm{mm}$ diameter). Specimens were then serially diluted in Virginia Polytechnic Institute dilution blanks (Holdeman et al., 1977) consisting of gelatin and inorganic salts solution. Within the anaerobic chamber, 100- $\mu$ l portions of these dilutions were spread on plates of the following media which had been poured in the chamber. 1: brucella blood agar, neomycin blood agar and kanamycin-vancomycin lysed-blood agar, prepared according to the methods of Sutter, Vargo and Finegold (1975), except that horse blood $10 \%$ was substituted for sheep blood $5 \%$. 2: Rogosa agar (Difco) with a final $p \mathrm{H}$ of 5.4 as a selective medium for lactobacilli.

After inoculation of these media for anaerobic incubation, the dilution tubes were removed from the chamber and 100- $\mu$ l samples were spread on plates of the following media for aerobic cultivation: Blood Agar (Tissue Culture Services, 10, Henry Road, Slough, Berks SL1 2QI), MacConkey agar (Oxoid), Sabouraud Dextrose Agar (Oxoid) and Modified Thayer-Martin medium (Riddell and Buck, 1970). All anaerobic culture plates were incubated in the chamber for up to 7 days at $35^{\circ} \mathrm{C}$, and the aerobic plates were incubated for 2 or 3 days at $35^{\circ} \mathrm{C}$ in an atmosphere of air $+5 \% \mathrm{CO}_{2}$. After incubation, the different types of colony were each counted and subcultured for identification, according to the methods of Cowan (1974) for aerobes and those of the Virginia Polytechnic Anaerobe Laboratory Manual (Holdeman et al., 1977) for anaerobes.

\section{RESULTS}

\section{Assessment of balance}

The ability of the balance to measure small masses accurately was not affected by the presence of a large mass $(p>0 \cdot 1$, Student's $t$ test). For a nominal mass of $0.02 \mathrm{~g}, 10$ or 12 repeat weighings in the presence (indirect) or absence (direct) of a $50 \mathrm{-g}$ mass gave similar mean values $(0.0196$ and 0.0195 , respectively) and range (0.0193-0.0198 and 0.0193-0.0199, respectively) and the same standard deviation $(0.00016)$ for each set. Thus it was suitable for measuring the very small increases of weight due to the vaginal secretion added to tubes of transport medium.

\section{Collection of samples by swab}

Indirect estimation of weight. The weights of vaginal secretion obtained on paired swabs from each patient are shown in table I. In a majority of cases there was good agreement between the weights of the two samples from each patient, irrespective of the type of swab used, but in about one third of cases there was a gross discrepancy between the weights collected. Correlation coefficients derived from the weights of the paired samples indicated moderately satisfactory agreement for the Q-tip and albumin-coated swabs, but poor agreement for the non-albumin-coated swabs (table I).

Homogenisation. For specimens taken with each type of swab, none of the three methods of homogenisation produced complete disintegration of the cotton fibres reported by other workers (Onderdonk et al., 1977). The recovery studies with $S$. aureus indicated that recovery rates of bacteria added to swabs and homogenised in the transport medium were consistently poor, irrespective of the homogenisation procedure and in contrast to those for organisms added directly to the medium (table II). 
TABLE I

Correlation between weights of vaginal secretion collected with paired swabs of different type

\begin{tabular}{|c|c|c|c|c|}
\hline \multirow[b]{2}{*}{ Type of swab } & \multirow{2}{*}{$\begin{array}{c}\text { Patient } \\
\text { no. }\end{array}$} & \multicolumn{2}{|c|}{ Weight of secretion $(\mathrm{g})$ on } & \multirow{2}{*}{$\begin{array}{c}\text { Correlation } \\
\text { coefficient }\end{array}$} \\
\hline & & 1st swab & 2nd swab & \\
\hline Q-tip & $\begin{array}{r}1 \\
2 \\
3 \\
4 \\
5 \\
6 \\
7 \\
8 \\
9 \\
10\end{array}$ & $\begin{array}{l}0.055 \\
0.081 \\
0.040 \\
0.112 \\
0.121 \\
0.018 \\
0.039 \\
0.024 \\
0.053 \\
0.067\end{array}$ & $\begin{array}{l}0.095 \\
0.081 \\
0.081 \\
0 \cdot 166 \\
0 \cdot 160 \\
0.044 \\
0 \cdot 028 \\
0 \cdot 015 \\
0 \cdot 016 \\
0.030\end{array}$ & $0 \cdot 86$ \\
\hline $\begin{array}{l}\text { Exogen } \\
\text { non-albumin- } \\
\text { coated }\end{array}$ & $\begin{array}{l}11 \\
12 \\
13 \\
14 \\
15 \\
16 \\
17 \\
18 \\
19 \\
20 \\
21 \\
22 \\
23 \\
24 \\
25 \\
26 \\
27 \\
28 \\
29\end{array}$ & $\begin{array}{l}0.128 \\
0.050 \\
0.060 \\
0.097 \\
0.076 \\
0.159 \\
0.057 \\
0.038 \\
0.113 \\
0.025 \\
0.019 \\
0.028 \\
0.199 \\
0.156 \\
0.135 \\
0.035 \\
0.022 \\
0.075 \\
0.064\end{array}$ & $\begin{array}{l}0.091 \\
0.063 \\
0.082 \\
0.089 \\
0.059 \\
0.085 \\
0.046 \\
0.049 \\
0.092 \\
0.042 \\
0.028 \\
0.007 \\
0.085 \\
0.054 \\
0.147 \\
0.099 \\
0.018 \\
0.088 \\
0.089\end{array}$ & $0 \cdot 56$ \\
\hline $\begin{array}{l}\text { Exogen } \\
\text { albumin-coated }\end{array}$ & $\begin{array}{l}30 \\
31 \\
32 \\
33 \\
34 \\
35 \\
36 \\
37 \\
38 \\
39 \\
40 \\
41 \\
42 \\
43 \\
44 \\
45 \\
46 \\
47 \\
48 \\
49\end{array}$ & $\begin{array}{l}0.023 \\
0.105 \\
0.197 \\
0.129 \\
0.059 \\
0.038 \\
0.050 \\
0.062 \\
0.024 \\
0.083 \\
0.064 \\
0.106 \\
0.029 \\
0.022 \\
0.038 \\
0.019 \\
0.091 \\
0.088 \\
0.075 \\
0.037\end{array}$ & $\begin{array}{l}0.018 \\
0.100 \\
0.181 \\
0.151 \\
0.124 \\
0.046 \\
0.050 \\
0.035 \\
0.031 \\
0.045 \\
0.050 \\
0.065 \\
0.045 \\
0.035 \\
0.047 \\
0.021 \\
0.068 \\
0.106 \\
0.018 \\
0.035\end{array}$ & $0 \cdot 82$ \\
\hline
\end{tabular}


TABLE II

Bacteriological assessment of homogenisation

\begin{tabular}{|c|c|c|c|c|}
\hline $\begin{array}{l}\text { Method of } \\
\text { addition } \\
\text { of } S \text {. aureus* }\end{array}$ & $\begin{array}{l}\text { Number of } \\
\text { S. aureus added } \\
(\mathrm{cfu} / \mathrm{ml})\end{array}$ & $\begin{array}{l}\text { Homogenisation method } \\
\text { and time } \\
\text { (min) }\end{array}$ & $\begin{array}{l}\text { Post-homogenisation } \\
\text { viable count } \\
\text { (mean cfu } / \mathrm{ml})^{+}\end{array}$ & $\begin{array}{l}\text { Recovery of organisms } \\
\text { (percentage of inoculum) }\end{array}$ \\
\hline By swab & $1.4 \times 10^{6}$ & $\begin{array}{c}\text { Vortex alone } \\
1 \\
2 \\
5 \\
10\end{array}$ & $\begin{array}{l}2.8 \times 10^{4} \\
4.5 \times 10^{4} \\
2.6 \times 10^{5} \\
9 \cdot 6 \times 10^{4}\end{array}$ & $\begin{array}{r}2.0 \\
3.2 \\
18.8 \\
6.9\end{array}$ \\
\hline By swab & $1.3 \times 10^{6}$ & $\begin{array}{c}\text { Vortex with } 1,2 \mathrm{~mm} \text { beads } \\
10\end{array}$ & $\begin{array}{l}6.3 \times 10^{4} \\
7.6 \times 10^{4} \\
1.1 \times 10^{5} \\
4.3 \times 10^{5}\end{array}$ & $\begin{array}{r}4 \cdot 8 \\
5 \cdot 8 \\
8 \cdot 5 \\
33 \cdot 1\end{array}$ \\
\hline By swab & $1.2 \times 10^{6}$ & Vortex with $3-5 \mathrm{~mm}$ beads & $\begin{array}{l}5.9 \times 10^{4} \\
1.2 \times 10^{5} \\
3.6 \times 10^{5} \\
4.7 \times 10^{5}\end{array}$ & $\begin{array}{r}4 \cdot 9 \\
10 \cdot 0 \\
30 \cdot 0 \\
39 \cdot 1\end{array}$ \\
\hline By swab & $1.2 \times 10^{6}$ & Stomacher with $1-2 \mathrm{~mm}$ beads & $\begin{array}{l}4.7 \times 10^{5} \\
6.0 \times 10^{4} \\
5.8 \times 10^{4} \\
8.7 \times 10^{4} \\
1.1 \times 10^{5}\end{array}$ & $\begin{array}{l}5 \cdot 0 \\
4 \cdot 8 \\
5 \cdot 8 \\
9 \cdot 2\end{array}$ \\
\hline Directly to tube & $1.6 \times 10^{6}$ & $\begin{array}{c}\text { Vortex with } 12 \mathrm{~mm} \text { beads } \\
1 \\
2 \\
5 \\
10\end{array}$ & $\begin{array}{l}1.7 \times 10^{6} \\
1.6 \times 10^{6} \\
1.1 \times 10^{6} \\
1.4 \times 10^{6}\end{array}$ & $\begin{array}{r}106 \cdot 2 \\
100 \cdot 0 \\
68.8 \\
87.5\end{array}$ \\
\hline
\end{tabular}

* See Materials and methods.

+ All tests were done in duplicate.

\section{Collection of samples by loop or pipette}

Sampling by volume. With loops and with pipettes, it was usually easy to collect the required volume of vaginal secretion, although it was occasionally difficult with the loop if the secretion was very sparse. It was often difficult, however, to expel secretion from a pipette because of adhesion to its sides and this method was discontinued. The weight of secretion obtained with a calibrated $10-\mu$ l loop varied widely, 10 samples giving the following values: $0.029,0.006,0.008$, $0.010,0.011,0.042,0.072,0.006,0.014$ and $0.005 \mathrm{~g}$ (mean $0.020 \mathrm{~g}$ ).

Sampling by weight. Uncalibrated Pastette "S" sterile transfer pipettes also provided a problem with expulsion and it was occasionally impossible to expel any secretion at all from the pipette into the transport medium for reweighing. No such problems occurred with a conventional bacteriological loop. Examples of the calculated weights for samples taken by loop from several different patients are shown in table III, which also gives the results of the bacteriological analysis, indicating the variety of organisms isolated and their concentrations in terms of the weight of each specimen.

Homogenisation. With all samples collected by loop or pipette, each of the three homogenisation methods caused rapid disintegration of the vaginal mucus of secretions added to transport medium, indicating efficient dispersal.

\section{DisCUSSION}

This study illustrates the difficulties encountered with existing methods of obtaining a known weight or volume of vaginal secretion for quantitative bacteriology. Other workers have reported correlation coefficients for paired swabs of 0.92 ( 6 volunteers) and 0.74 ( 80 volunteers), respectively, without indicating the actual weights of secretion collected (Bartlett et al., 1977; Onderdonk et al., 1977). However, in this study, although two types of swab (Q-tips and Exogen albumin-coated) provided comparable correlation coefficients $(0.86$ and 0.82 respectively), there were very great differences of weight between the two specimens collected in about a third of the samples indicating that this indirect paired-swab method is unsuitable for quantitative bacteriological studies. A direct method, in which a single weighed-swab analysis was used, also proved inadequate, because the bacteriological recovery studies showed that 
TABLE III

Identity and concentration of organisms isolated from vaginal secretion by weight-based loop collection

\begin{tabular}{|c|c|c|c|c|c|}
\hline \multirow[b]{3}{*}{ Patient } & \multirow{2}{*}{\multicolumn{2}{|c|}{$\begin{array}{l}\text { Weight }(\mathrm{g}) \text { of tube of transport } \\
\text { medium }\end{array}$}} & \multirow{3}{*}{$\begin{array}{l}\text { Weight } \\
\text { (g) of } \\
\text { specimen }\end{array}$} & \multicolumn{2}{|l|}{ Organisms cultured } \\
\hline & & & & \multirow[b]{2}{*}{ Identity } & \multirow{2}{*}{$\begin{array}{l}\text { Concentration } \\
\text { in specimen } \\
\left(\log _{10} \mathrm{cfu} / \mathrm{g}\right)\end{array}$} \\
\hline & $\begin{array}{l}\text { before addition } \\
\text { of specimen }\end{array}$ & $\begin{array}{l}\text { after addition } \\
\text { of specimen }\end{array}$ & & & \\
\hline \multirow[t]{4}{*}{ A } & $32 \cdot 9856$ & $33 \cdot 0101$ & 0.0245 & Lactobacillus sp. & $5 \cdot 9$ \\
\hline & & & & Corynebacterium sp. & $6 \cdot 4$ \\
\hline & & & & Propionobacterium sp.* & $\begin{array}{l}9.3 \\
7 \cdot 3\end{array}$ \\
\hline & & & & Peptococcus variabilis & 8.9 \\
\hline \multirow[t]{4}{*}{ B } & $33 \cdot 0147$ & 33.0303 & 0.0156 & Staphylococus epidermidis & $6 \cdot 7$ \\
\hline & & & & $\alpha$-haemolytic streptococcus & $2 \cdot 9$ \\
\hline & & & & Peptostreptococcus sp.* & $8 \cdot 5$ \\
\hline & & & & Bacteriodes fragilis** & $5 \cdot 8$ \\
\hline \multirow[t]{4}{*}{$\mathrm{C}$} & $33 \cdot 0359$ & $33 \cdot 0685$ & 0.0326 & Lactobacillus sp. & $5 \cdot 0$ \\
\hline & & & & Propionobacter sp.* & $5 \cdot 4$ \\
\hline & & & & Peptostreptococcus intermedius & $3 \cdot 2$ \\
\hline & & & & Candida albicans & $4 \cdot 3$ \\
\hline \multirow[t]{4}{*}{$\mathrm{D}$} & $32 \cdot 8111$ & $32 \cdot 8197$ & 0.0086 & Lactobacillus sp. & $8 \cdot 4$ \\
\hline & & & & Corynebacterium sp. & $3 \cdot 2$ \\
\hline & & & & Veillonella alcalescens* & $8 \cdot 3$ \\
\hline & & & & Peptococcus prevoti* & $7 \cdot 3$ \\
\hline \multirow[t]{5}{*}{$\mathrm{E}$} & $33 \cdot 1821$ & $33 \cdot 1905$ & 0.0084 & Lactobacillus sp. & $7 \cdot 4$ \\
\hline & & & & Peptococcus prevoti ${ }^{*}$ & $8 \cdot 0$ \\
\hline & & & & Peptostreptococcus sp.* & $5 \cdot 7$ \\
\hline & & & & Streptococcus faecalis & $3 \cdot 0$ \\
\hline & & & & Escherichia coli & $7 \cdot 3$ \\
\hline \multirow[t]{6}{*}{$\mathrm{F}$} & $32 \cdot 8697$ & $32 \cdot 8893$ & 0.0196 & Corynebacterium sp. & $4 \cdot 0$ \\
\hline & & & & Staphylococcus epidermidis & $2 \cdot 5$ \\
\hline & & & & Lactobacillus sp.* & $7 \cdot 9$ \\
\hline & & & & Peptococcus magnus* & $3 \cdot 5$ \\
\hline & & & & Peptococcus prevoti* & $3 \cdot 3$ \\
\hline & & & & Bacteroides melaninogenicus* & 4.9 \\
\hline
\end{tabular}

* Anaerobic species.

various homogenisation techniques failed to release the majority of organisms from a deliberately inoculated swab. Similar conclusions were reached by Collee et al. (1974), who found that test swabs containing a known number of organisms yielded only $3-5 \%$ of the inoculum when plated directly onto solid media and only 16-25\% when agitated in glucose broth.

In view of the above difficulties, the use of swabs was abandoned and methods of sampling by loop or pipette were assessed. Simultaneously, the modified Cary-Blair transport medium, lacking agar and with an additional reducing agent, was introduced, the absence of the agar making disintegration of the vaginal mucus easier to observe. Collection by pipette proved unsatisfactory because of difficulties of expelling secretions and loops were therefore preferred. Calibrated loops to collect a defined volume of secretion were found to be satisfactory by Levison et al. (1977), but not by Onderdonk et al. (1977) who reported ranges of weight for vaginal samples even more widely variable than those we obtained with calibrated loops, indicating their unreliability for volumetric sampling. Our preferred method, in which loopfuls of secretion are added to a weighed tube of transport medium has the advantage of being direct, free from homogenisation difficulties and independent of differences in viscosity and density of secretion. So far, we have not encountered problems with this method and the bacteriological results obtained from the first few patients studied appear comparable with those of other reports on the composition and concentration of the human vaginal flora.

The concept of aerobic lactobacilli as the "dominant" organisms of the vaginal flora has gradually been modified as a result of the use of quantitative methods and improved anaerobic 
techniques. The complexity of the vaginal flora, the large number of different species isolated and the importance of anaerobic species, especially anaerobic cocci, can clearly be seen in our results, even from the small sample of patients studied. A more detailed report, based on examination of single and repeated samples from asymptomatic and symptomatic women, is being prepared.

This work was supported by a grant from the Joint Research Board of St Bartholomew's Hospital. Thanks are due to Miss Lorraine Hall for typing the manuscript.

\section{REFERENCES}

Bartlett, J. G., Onderdonk, A. B., Drude, E., Goldstein, C., Anderka, M., Alpert, S. And MCCormack, W. M. 1977. Quantitative bacteriology of the vaginal flora. J. infect. Dis., 136, 271.

Clarke, R. T. J. 1977. In The microbial ecology of the gut, edited by R. T. J. Clarke and T. Bauchop, London, Academic Press, p. 1.

Collee, J. G., Watt, B., Brown, R. and Johnstone, S. 1974. The recovery of anaerobic bacteria from swabs. J. Hyg., Camb., 72, 339.

Cowan, S. T. 1974. Cowan and Steel's Manual for the identification of medical bacteria, 2nd ed., Cambridge University Press, Cambridge.

Galask, R. P., LARSEN, B. AND OHM, M. J. 1976. Vaginal flora and its role in disease entities. Clin. Obstets Gynaec., 19, 61.

Holdeman, L. V., Cato, E. P. AND Moore, W. E. C. 1977. Anaerobe laboratory manual, 4th ed., Virginia Polytechnic Institute and State University, Blacksburg, Virginia.

Hungate, R. E. 1950. The anaerobic mesophilic cellulolytic bacteria. Bact. Rev., 14, 1.

Levison, M. E., Corman, L. C., Carrington, E. R. and Kaye, D. 1977. Quantitative microflora of the vagina. Am. J. Obstet. Gynec., 127, 80.

Lindner, J. G. E. M., Plantema, F. H. F. and Hoogkamp-Korstanje, J. A. A. 1978. Quantitative studies of the vaginal flora of healthy women and of obstetric and gynaecological patients. J. med. Microbiol., 11, 233.

Onderdonk, A. B., Polk, B. F., Moon, N. E., Goren, B. and Bartlett, J. G. 1977. Methods for quantitative vaginal flora studies. Am. J. Obstet. Gynec., 128, 777.

RIDDELL, R. H. AND BUCK, A. C. 1970. Trimethoprim as an additional selective agent in media for the isolation of N. gonorrhoeae. J. clin. Path., 23, 481.

SutTER, V. L., VARGO, V. L. AND FineGOLD, S. M. 1975. Wadsworth anaerobic bacteriology manual, 2nd ed., University Extension and School of Medicine U.C.L.A., Los Angeles.

TABAQCHALI, S. 1970. The pathophysiological role of small intestinal bacterial flora. Scand.J. Gastroenterol., 5, suppl. 6, 139.

TABaQChali, S., Fiddian, A. P. AND AtKinson, P. 1979. Recent techniques in the investigation and diagnosis of anaerobic infections. J. Infect., 1, suppl. 1, 13. 